\title{
Online Education during COVID-19: Prospects and Challenges in Bangladesh
}

Dr Tulshi Kumar Das ${ }^{+}$

\section{Abstract}

COVID-19 has forced the authorities to introduce online education at all levels in Bangladesh. Students from primary to tertiary levels had initial hiccups to adapt to the newly introduced online education system because of genuine reasons like lack of appropriate device, absence or limited access to internet networks, disinterest in online education, disruption in electricity, etc. Perhaps, most of the stakeholders involved in education had a kind of hope of witnessing the crisis caused through COVID-19 over within a short period of time. Thus, none of the stakeholders was very serious in online education, expecting offline in-person education to be back pretty soon. It seems to have been realised by most of the stakeholders after almost one and a half years of the corona crisis that the pandemic may not disappear quickly. As a result, online education has recently been reinforced in Bangladesh, considering it the only alternative to the previous system. This review study explores the prospects and challenges of online education in the context of Bangladesh and finds out that prospects of it could be pretty high as an alternative education system. However, its challenges may be described as daunting given the socioeconomic and cultural constraints that prevail in the country.

Keywords: COVID-19; Online Education; Prospects and Challenges; Bangladesh

\footnotetext{
+ Professor, Department of Social Work, Shahjalal University of Science and Technology Sylhet-3114, Bangladesh, Email: tulshikumardas@gmail.com

(C) 2021 Das. This is an Open Access article distributed under the terms of the Creative Commons Attribution License (http://creativecommons.org/licenses/by/2.0), which permits unrestricted use, distribution, and reproduction in any medium, provided the original work is properly cited.
} 


\section{Background}

The entire world has been struggling hard to fight out COVID-19 over the last one and a half years or more, and it still remains uncertain when the struggle will come to an end, confirming the humanity survive without fear and further loss of human lives. COVID-19 originated from Wuhan, China, in December 2019, spread worldwide within a very short period of time, killing 42,29,249 and infecting $198,259,318$ people to date (Rahman, Peeri, Shrestha, Zaki, Haque, \& Hamid, 2020; Worldometer, 2021). The death toll in different parts of the world, especially in South Asia, South-East Asia and Latin America, has been alarmingly high in the last couple of months. Bangladesh has been reeling under the second wave of COVID-19 attack, crossing the death toll of more than 200 and infected over 13,000 every day in the last seven days. The total number of corona death from 3 January 2020 to 30 July 2021 is 20,467, and infected 1,240,115 in the country (WHO, 2021). Education amongst all other sectors is one of the worst-hit due to the COVID-19 pandemic as the Government of Bangladesh announced the closure of all educational institutions from 17 March 2020, which has still been continued in the face of the rapidly deteriorating COVID-19 situation (Khan, Rahman, \& Islam, 2021). From then onwards, the formal education system has been gradually collapsing in the absence of students-teachers in-person meeting in the physical classroom. Though some of the educational institutions, particularly private ones, introduced online education for their students from April 2020, the majority of the institutions across the country preferred to wait for being reopened. The government had no other option but to keep all the educational institutions shut for an indefinite time since the corona situation never substantially improved; instead, it worsened every day. Considering the long-time effects of COVID-19 and the continued shutdown of educational institutions, authorities of most of the schools, colleges and universities hurriedly decided to launch online education for their students without much preparation and wellplanned strategies (Alamgir, 2020; Khan, Rahman, \& Islam, 2021; Majed, Jamal, \& Kabir, 2020; Mondira \& Mahtab, 2021). Though online education has been launched in the majority of the institutions, the destination of this newly introduced online education has not been seriously aimed, failing to reach the goals of achieving the ultimate success. Hence, the students of all levels going through online classes, exams and other academic activities are evidently unable to benefit themselves from this new education system; despite this, virtual education seems to be having good prospects in the context of Bangladeshi society. It is evident that a developing country like Bangladesh has many complex challenges towards implementing online education successfully, but with a well-planned and comprehensive strategy along with strong commitment, online education could be made not only popular among all the stakeholders but also significantly beneficial for all concerned (Abdullah, 2020; Mondira \& Mahtab, 2021; Sarkar, Das, Rahman, \& Zobaer, 2021). Online education is believed to be the only alternative in the ongoing COVID-19 pandemic as 'social distancing' has been declared mandatory to prevent the infection, forcing the authorities not allowing the students to gather at the campus.

The study begins with a discussion on the prospects of online education. Following this, it describes the challenges of online education in Bangladesh.

\section{Prospects of Online Education}

Generally, online education has enormous prospects in the coming days across the globe (Agarwal \& Kaushik, 2020; Palvia, Aeron, Gupta, Mahapatra, Parida, Rosner, \& Sindhi, 2018). It is slowly becoming popular in the developed countries, primarily it has gathered considerable momentum in the face of the COVID-19 pandemic in Europe, Australia, New Zealand, America, as well as many of the developing countries (Bao, 2020; Basilaia, Dgebuadze, Kantaria, \& Chokhonelidze, 2020; Ferri, Grifoni, \& Guzzo, 2020). Thus, education system has not 
been interrupted much there as it has been happening in the developing world. A developing country like Bangladesh still struggles to be used to online education, causing extensive interruptions in the educational system. Bangladesh has already moved to online education after the shutdown of all educational institutions, but slowly.

Arguably, online education may be described as still under experimentation in Bangladesh. The experience of students and teachers involved in online education is not entirely bad. Students and instructors can join the class anytime (day and evening) with an appropriate device (Khan, Rahman, \& Islam, 2021; Majed, Jamal, \& Kabir, 2020). There is no preparation needed like hurriedly taking breakfast, wearing a proper outfit and reaching the classroom right on time. Students can enjoy the class more closely here than in a traditional classroom, looking at the screen and listening to the lecture from a nearer distance. The instructor may show relevant videos, image, published articles, or other educational materials, taking them instantly from the websites if required. The entire lecture delivered by the instructor is expected to be recorded so that students absent in the class or the students who want to enjoy the class again for more profound understanding can easily play it as many times as needed. Students can enjoy more freedom in an online class as anybody not liking the class may leave without seeking permission from the teacher. Attending class, raising questions, appearing in the exams, presenting assignments and uploading the same, facing the viva-voce etc. could easily be carried out in online education without much physical labor, and psychological stress as the students do everything from their home where they are supposed to be comfortable around their family members (Majed, Jamal, \& Kabir, 2020). Online education pushes the students more for selflearning, helping them explore their own interests and act accordingly with the help of internet networks. It is utterly hassle-free because of physical non-involvement in a digital classroom. During the time of COVID-19, online education could be a blessing even in a country like Bangladesh, as the learning can be continued without disruptions in an emergency situation that helps the students feel good (Sarkar, Das, Rahman, \& Zobaer, 2021; Majed, Jamal, \& Kabir, 2020). Online education prevents the students from sitting idle at home and developing trauma because of frequent death and infection witnessing around caused through COVID-19. The guardians of the students can also see their children participating in an online class from home itself, which gives them a good feeling amidst the COVID-19 crisis. Students frequently meeting the teachers through online interactions during the class lecture in a situation of emergency generally boosts their mental strength, preventing them from being depressed (Khan, Rahman, \& Islam, 2021). Students can also chat with each other during the online class or before attending the class, sharing their stories with their classmates that release their stress to an extent in the ongoing pandemic situation. Thus, online education can generate a space for the students to be more creative with the help of multiple digital sources of knowledge during COVID-19, and it is also to be noted that online education will be a reality within less than a decade in the digitalised globe. Bangladesh should fully utilise the potentials of online education with no more delays.

\section{Challenges Associated with Online Education}

Despite the prospects of online education in Bangladesh, multifarious challenges may be identified, which need to be addressed to make it successful (Al-Amin, Al Zubayer, Deb, \& Hasan, 2021). Though the government of Bangladesh claimed that the total number of internet users in the country was 103.253 million and mobile phone users were 165.337 million by the end of March 2020, nobody knew about the exact number of people who had the appropriate digital device for having access to stable internet networks. Moreover, people's internet use depends on their social class, cultural background, gender identity, rural-urban context, ethnicity, disability, etc. It clearly indicates that people from all walks of life do not have equal access to internet networks (Abdullah, 2020; Chowdhury, 2020; Khan, Rahman, \& Islam, 2021; Sarkar, Das, Rahman, \& 
Zobaer, 2021). A study conducted by Brac.net (2020) reveals that $44.1 \%$ of the students of primary and secondary levels participate in the online class, and the rest, $55.9 \%$, do not participate. Of those who have madrasa (Islamic school) background, only $32.4 \%$ of them can participate in the online class, and on the other hand, $45.9 \%$ of the students with Bangla medium join in a virtual class. From the rural and urban areas, only $39.8 \%$ and $55.8 \%$ of the students respectively can enjoy digital class, and the rest cannot participate. The study further shows that $45.5 \%$ of girls and $42.7 \%$ of boys generally participate in online classes.

Interestingly, the participation of girls from primary and secondary schools in an online class is slightly more than that of boys. Those who do not participate in a virtual class, $71.2 \%$ of them said that they did not have an appropriate device and other logistic supports, $20.5 \%$ of them told that they were not well informed about the online class, and $4.5 \%$ showed no interest in virtual class (Brac. net, 2020). Surprisingly, only $23 \%$ of the students of public, private universities and affiliated colleges were found enjoying online classes, and the rest, $77 \%$ of them simply opposed online classes during COVID-19. This is also a fact that only $55.3 \%$ of these students had an appropriate device to participate in the online class, and the rest did not have. Weak internet networks and low speed, especially outside the capital city, Dhaka, also discourage students from joining online classes (Al-Amin, Al Zubayer, Deb, \& Hasan, 2021). Around $55 \%$ of these students do not have proper internet networks, struggling to enjoy the virtual class fully. It is noteworthy to mention that, on average, $40 \%$ of students of public and private universities and affiliated colleges currently participate in a virtual class, of which around $70 \%$ are from private universities. It has also been shown that $87 \%$ of the students feel that online assignment kind of assessment is worthless, and $82 \%$ of the students do not consider online classes as effective as an inperson class (Islam, Tanvir, Amin \& Salman, 2020; Khan, Rahman, \& Islam, 2021). Apart from the challenges mentioned earlier, my observation as an academic (first-hand experience) is that many teachers and students need to be trained in online classes since they are not skilled and therefore found least interested in it. A substantial number of university students do not attend online classes without any valid reasons. Female university students confined within a home due to this ongoing prolonged lockdown are often asked by the parents to engage in household chores, resulting in missing online classes from time to time. Sitting idle at home for such a long time without study causes the students to have traumatic experiences, coercing them to feel demotivated and discouraged towards study, which could be a reason for intentionally missing online classes. Another critical observation may also be noted that students of different academic disciplines need to be engaged in practical learning in the laboratory, industry, community, organizations, excursion, etc., for a fixed time, which has been postponed since the pandemic started. Online education has excluded all practical learnings in Bangladesh.

\section{Conclusion}

The online class introduced in Bangladesh during COVID-19 is not well-planned. It was initially launched as a temporary arrangement to compensate for the perceived gap in education due to the shutdown of educational institutions. Authorities perhaps hoped to get back to inperson class as quickly as possible once the shutdown lifted. Since the COVID-19 situation deteriorates and the shutdown continues indefinitely, the online class is considered the only alternative to save the overall education system from being collapsed. Thus, the authorities seem to have become serious now in online education, thinking of running online education in a more well-coordinated and stringent way to make the students understand its inevitability. A considerable number of students do not participate in the online class, and many of them have genuine socioeconomic and cultural constraints that force them to refrain from participating in online education. Many other challenges are putting solid barriers to the ways of realising online education in Bangladesh. A well-thought policy is required to 
take the genuine challenges into account before going into its full-fledged implementation. Additionally, the online education system needs to be institutionalized, aiming to develop a culture of virtual learning among the students and teachers and in the greater society.

\section{References}

Abdullah, M. (2020, December 31). 2020: The rise of online education. Dhaka Tribune. https://www.dhakatribune.com/bangladesh/20 20/12/31/2020-rise-of-online-education

Agarwal, S., \& Kaushik, J. S. (2020). Student's perception of online learning during COVID pandemic. Indian J. Pediatr. 87, 554. doi:10.1007/s12098-020-03327-7

Alamgir, M. (2020, April 30). Ensure online classes: Ministry, UGC to all universities. The Daily Star.

https://www.thedailystar.net/online/news/ens ure-online-classes-ministry-ugc-all-universities1898335

Al-Amin, M., Al Zubayer, A., Deb, B., and Hasan, M. (2021). Status of tertiary level online class in Bangladesh: Students' response on preparedness, participation and classroom activities. Heliyon 7 (1), e05943. doi:10.1016/j.heliyon.2021.e05943

Bao, W. (2020). COVID-19 and online teaching in higher education: A case study of Peking University. Human Behavior and Emerging Technologies, (2), 113-115.

https://doi.org/10.1002/hbe2.191

Basilaia, G., Dgebuadze, M., Kantaria, M., \& Chokhonelidze, G. (2020). Replacing the classic learning form at universities as an immediate response to the COVID-19 virus infection in Georgia. International Journal for Research in Applied Science \& Engineering Technology (IJRASET), 8(3), 101-108.

http://doi.org/10.22214/ijraset.2020.3021

Brac.net (2020). A rapid assessment impact of COVID-19 on education in Bangladesh. http://www.brac.net/program/wpcontent/uploads/2020/07/Rapid-assessmentimpact-of-COVID-19-education-in-
Bangladesh.pdf?fbclid=IwAROgptxwHSBLBsiii5H LsGzFfroELwt-XnCgL1ElJBJvufYJBhLw7siWIYA

Chowdhury, I. A. (2020, December 8).

Bangladeshi children share experiences of remote learning and the challenges they face. UNICEF.

https://www.unicef.org/bangladesh/en/stories/ bangladeshi-children-share-experiencesremote-learning-and-challenges-they-face

Ferri, F., Grifoni, P., \& Guzzo, T. (2020). Online learning and emergency remote teaching: Opportunities and challenges in emergency situations. Societies, 10(4), 86. https://doi.org/10.3390/soc10040086 Islam, M. S., Tanvir, K. M., Amin, M., \& Salman, M. (2020). Online classes for university students in Bangladesh during the COVID-19 pandemicis it feasible?

https://www.tbsnews.net/thoughts/onlineclasses-university-students-bangladesh-duringcovid-19-pandemic-it-feasible-87454

Khan, M. M., Rahman, S. M. T. \& Islam, S. T. A. (2021). Online education system in Bangladesh during COVID-19 pandemic. Creative Education, 12, 441-452.

https://doi.org/10.4236/ce.2021.122031

Majed, N., Jamal, G. R. A. \& Kabir, M. R. (2020, July 28). Online education: Bangladesh perspective, challenges and way forward. The Daily Star.

https://www.thedailystar.net/online/news/onli ne-education-bangladesh-perspectivechallenges-and-way-forward-1937625

Mondira, R. T. \& Mahtab, M. (2021, April 23). The realities of online education in Bangladesh. The Daily Star.

https://www.thedailystar.net/staryouth/news/the-realities-online-educationbangladesh-2082453

Palvia, S., Aeron, P., Gupta, P., Mahapatra, D., Parida, R., Rosner, R., \& Sindhi, S. (2018). Online Education: Worldwide status, challenges, trends and implications. Journal of Global Information Technology Management, 21(4), 233-241. doi: 10.1080/1097198X.2018.1542262 
Rahman, M. S., Peeri, N. C., Shrestha, N., Zaki, R., Haque, U., \& Hamid, S. H. (2020). Defending against the novel coronavirus (COVID-19) outbreak: How can the Internet of Things (IoT) help to save the world? Health Policy Technol, 9 (2), 136-138. doi:10.1016/j.hlpt.2020.04.005

Sarkar, S. S., Das, P., Rahman, M. M., \& Zobaer, M. S. (2021). Perceptions of public university students towards online classes during COVID19 pandemic in Bangladesh. Frontiers in Education, 6,703723.

https://doi.org/10.3389/feduc.2021.703723

Worldometer. (2021, July 31). COVID-19 coronavirus pandemic.

https://www.worldometers.info/coronavirus/? utm_campaign=homeAdvegas 1 ?
WHO (World Health Organization). (2021, July 31). Bangladesh.

https://covid19.who.int/region/searo/country/ bd

\section{Conflict of Interest}

I hereby declare that I have no conflict of interest.

\section{Acknowledgements}

This is a solicited article. However, I am highly grateful to the in-house reviewers for their critical comments on the manuscript. The comments of the in-house reviewers have helped to improve the quality of this brief communication. 